\title{
Considering Participants' Personal Wellness in Conservation-Based Extension Programs: Opportunities for Integrative Development and Evaluation ${ }^{1}$
}

\author{
John Diaz, Erica Odera, and Laura Warner ${ }^{2}$
}

\section{Abstract}

Extension organizations are at the forefront of water resource issues, using educational programs to drive participant behaviors toward water conservation. The effectiveness of these efforts centers on designing programs with considerations of the factors that will change relevant decisions and behaviors among residential landscape water users. We conducted a statewide study to explore the concept of wellness and well-being, and these characteristics' relationship to water conservation behaviors. Our results show that psychosocial measures influence current and future residential landscape water conservation behaviors differently. Perception of well-being is the more consistent predictor for both current behaviors and future intentions. These results demonstrate an opportunity for those focused on environmental behaviors to pair and embed programs focused on personal well-being to empower communities to work toward achieving conservation goals.

\section{Introduction}

Water scarcity is a rapidly growing concern across the globe as the world's population continues to increase. Extension organizations are among those at the forefront of this issue using educational programs to drive behavior change toward more water conservation (Kumar Chaudhary et al., 2017; Warner et al., 2018). The efficacy of educational endeavors hinges on designing and delivering programs with considerations of the factors that will change relevant decisions and behaviors among residential water users (Kumar Chaudhary et al., 2017). While technological, infrastructural, and educational foci have been applied to this issue (e.g., Clark \& Finley, 2007; Lam, 2006; Kumar Chaudhary et al., 2017; Willis et al., 2011), much less attention has been given to psychosocial factors, which may influence residential landscape water conservation behavior.

What types of decisions and behaviors do we engage in when under personal stress or financial pressure? Likewise, what types of decisions and behaviors occur when we are content and happy? Past research (Binder \& Blankenberg, 2017; Caceda et al., 2014; Cisler \& Koster, 2010; Leykin et al., 2011; Porcelli \& Delgado, 2017; Treadway et al., 2013; Welsch \& Kühling, 2018) on mental wellness and perceptions of well-being influence our decisions and our actions.

1. This document is AEC707, one of a series of the Department of Agricultural Education and Communication, UF/IFAS Extension. Original publication date October 2020. Visit the EDIS website at https://edis.ifas.ufl.edu for the currently supported version of this publication.

2. John Diaz, assistant professor and Extension specialist, program development and evaluation, Department of Agricultural Education and Communication, UF/IFAS Gulf Coast Research and Education Center, Plant City, FL; Erica Odera, monitoring and evaluation specialist, UF/IFAS Livestock Systems Innovation Lab; and Laura Warner, associate professor and Extension specialist, Department of Agricultural Education and Communication, UF/IFAS Extension, Gainesville, FL 32611.

The Institute of Food and Agricultural Sciences (IFAS) is an Equal Opportunity Institution authorized to provide research, educational information and other services

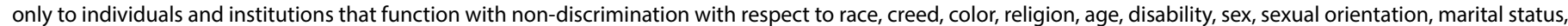

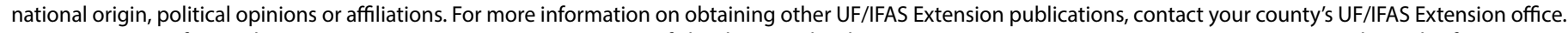
U.S. Department of Agriculture, UF/IFAS Extension Service, University of Florida, IFAS, Florida A \& M University Cooperative Extension Program, and Boards of County Commissioners Cooperating. Nick T. Place, dean for UF/IFAS Extension. 
However, research has not examined how mental wellness and well-being are related to outdoor water conservation behaviors and behavioral intent, an important topic for water conservation efforts. The research presented here was undertaken to better understand the influence of stress, happiness, and well-being on current behavior and future intent to conserve residential landscape water.

\section{Research Study and Results}

Data were collected in 2017 through an online survey of 1,809 adults nationwide who control and manage a household lawn that receives supplemental irrigation. Three validated scales were used to measure three different aspects of mental well-being: subjective happiness (Lyubomirksy \& Lepper, 1999), perceived stress (Cohen, Kamarck \& Mermelstein, 1983), and personal well-being (International Well-being Group, 2013). See the appendix for each of these validated scales. Two additional scales measured current engagement in household water conservation behavior and future intention to engage in household water conservation behavior.

To analyze the data, two logistical regression models were created: one that examined current water conservation practices and one that examined future water conservation intentions. The models explored the likelihood that a respondent would fall within a "high" or "low" water conservation category when considering their levels of stress, well-being, and subjective happiness.

We found both well-being and subjective happiness were statistically significant predictors of water conservation behavior, but stress was not. We also found that for future intentions of water conservation behavior, only well-being was a statistically significant predictor. Specifically, those who had a one-unit increase within the well-being index were approximately $22 \%$ more likely to be "high" water conservers with regard to their future intentions.

\section{Implications and}

\section{Recommendations}

Our findings provide a rationale for Extension educators and other nonformal educators to reconsider their current approach to achieving conservation goals and adopting a more holistic strategy that focuses on personal and community well-being. Providing new and accurate information, by itself, will not be sufficient to promote behavior change to conserve water. Below we provide salient recommendations for Extension programs based on our study results.
- Extension educators and other nonformal educators should consider pairing and embedding programs focused on personal and family well-being with programs focused on environmental behavior. Given the connection between well-being and residential landscape water conservation behaviors, it makes sense to connect programming across these two areas. These types of interdisciplinary programs can provide new opportunities for programming that meets the needs of today's Extension audiences. Perhaps Family, Youth and Community Science Extension professionals can embed environmental conservation topics in their nutrition or financial programs. For example, integrating education on water conservation into a household budgeting workshop may provide an opportunity for participants to understand the connection between conserving water and their economic wellness.

- Natural Resources educators should consider embedding support for participants' well-being into their programs. For example, incorporating such activities as nature walks and providing in-the-field opportunities for group interactions and learning have the opportunity to improve participants' mental and physical health (Marselle, Warber \& Irvine, 2019).

- The Robert Woods Johnson Foundation (2020) emphasizes that the well-being of our communities, our environment, and our planet are closely linked, and they call for well-being to guide decision-making and action. There is an opportunity for Extension educators to incorporate the concept of well-being into program evaluation using well-being indicators to inform programmatic improvements and measure success. Extension educators could consider collecting this type of data from potential program participants to help them understand their audience's needs in terms of overall well-being as well as their likelihood of adopting new behaviors. For example, audience members who score very low on well-being may require help in other areas before they are ready to think about adopting environmental conservation behaviors.

For more information about the study described here, please see Diaz, Odero, and Warner (2020), available at https://pubmed.ncbi.nlm.nih.gov/32364958/.

\section{References}

Binder, M., \& Blankenberg, A. K. (2017). Green lifestyles and subjective well-being: More about self-image than actual behavior? Journal of Economic Behavior \& Organization, 137, 304-323. doi:10.1016/j.jebo.2017.03.009. 
Cáceda, R., Nemeroff, C. B., \& Harvey, P. D. (2014). Toward an understanding of decision making in severe mental illness. The Journal of Neuropsychiatry and Clinical Neurosciences, 26(3), 196-213. doi:10.1097/PSY.0000000000000075.

Cisler, J. M., \& Koster, E. H. (2010). Mechanisms of attentional biases towards threat in anxiety disorders: An integrative review. Clinical Psychology Review, 30(2), 203-216. doi:10.1016/j.cpr.2009.11.003.

Clark, W. A., \& Finley, J. C. (2007). Determinants of water conservation intention in Blagoevgrad, Bulgaria. Society and Natural Resources, 20(7), 613-627. doi:10.1080/08941920701216552.

Cohen, S., Kamarck, T., \& Mermelstein, R. (1983). A global measure of perceived stress. Journal of Health and Social Behavior, 385-396. doi:10.2307/2136404.

Diaz, J. M., Odera, E., \& Warner, L. A. (2020). Delving deeper: Exploring the influence of psycho-social factors on water conservation behavior. Journal of Environmental Management, 264, 110404. doi:10.1016/j. jenvman.2020.110404.

International Well-being Group. (2013). Personal Wellbeing Index: 5th Edition. Retrieved from http://www.acqol. com.au/instruments\#measures.

Kumar Chaudhary, A., Warner, L. A., Lamm, A. J., Israel, G. D., Rumble, J. N., \& Cantrell, R. A. (2017). Using the theory of planned behavior to encourage water conservation among extension clients. Journal of Agricultural Education, 58(3), 185-202. doi:10.5032/jae.2017.03185.

Lam, S. P. (2006). Predicting intention to save water: Theory of planned behavior, response efficacy, vulnerability, and perceived efficiency of alternative solutions. Journal of Applied Social Psychology, 36(11), 2803-2824. doi:10.1111/j.0021-9029.2006.00129.x.

Leykin, Y., Roberts, C. S., \& DeRubeis, R. J. (2011). Decision-making and depressive symptomatology. Cognitive Therapy and Research, 35(4), 333-341. Retrieved from https://www.ncbi.nlm.nih.gov/pmc/articles/PMC3132433/.

Lyubomirsky, S., \& Lepper, H. S. (1999). A measure of subjective happiness: Preliminary reliability and construct validation. Social Indicators Research, 46(2), 137-155. doi:10.1023/A:1006824100041.
Marselle, M. R., Warber, S. L., \& Irvine, K. N. (2019). Growing resilience through interaction with nature: Can group walks in nature buffer the effects of stressful life events on mental health? International Journal of Environmental Research and Public Health, 16(6), 986. doi:10.3390/ ijerph16060986.

Porcelli, A. J., \& Delgado, M. R. (2017). Stress and decision making: Effects on valuation, learning, and risk-taking. Current Opinion in Behavioral Sciences, 14, 33-39. doi:10.1016/j.cobeha.2016.11.015.

Robert Woods Johnson Foundation (RWJF). (2020). Enhanced individual and community well-being. Retrieved from https://www.rwjf.org/en/cultureofhealth/takingaction/outcome-improved-population-health--well-being-and-equity/individual-and-community-well-being.html.

Treadway, M. T., Buckholtz, J. W., \& Zald, D. (2013). Perceived stress predicts altered reward and loss feedback processing in medial prefrontal cortex. Frontiers in Human Neuroscience, 7, 180. doi:10.3389/fnhum.2013.00180.

Welsch, H., \& Kühling, J. (2018). How green self image is related to subjective well-being: Pro-environmental values as a social norm. Ecological Economics, 149, 105-119. doi:10.1016/j.ecolecon.2018.03.002.

Willis, R. M., Stewart, R. A., Panuwatwanich, K., Williams, P. R., \& Hollingsworth, A. L. (2011). Quantifying the influence of environmental and water conservation attitudes on household end use water consumption. Journal of Environmental Management, 92(8), 1996-2009. doi:10.1016/j. jenvman.2011.03.023.

Warner, L. A., Diaz, J. M., \& Chaudhary, A. K. (2018). Informing urban landscape water conservation extension programs using behavioral research. Journal of Agricultural Education, 59(2), 32-48. doi:10.5032/jae.2018.02032. 


\section{Appendix}

\section{Subjective Happiness Scale}

1. In general, I consider myself:

$\begin{array}{llllll}1 & 2 & 3 & 4 & 5 & 6\end{array}$

2. Compared to most of my peers, I consider myself:

$\begin{array}{lllllll}1 & 2 & 3 & 4 & 5 & 6 & 7 \\ \text { less happy } & & & & & \text { more happy }\end{array}$

3. Some people are generally very happy. They enjoy life regardless of what is going on, getting the most out of everything. To what extent does this characterization describe you?

$\begin{array}{llllllc}1 & 2 & 3 & 5 & 6 & 6 & 7 \\ \text { not at all } & & & & & \text { a great deal }\end{array}$

4. Some people are generally not very happy. Although they are not depressed, they never seem as happy as they might be. To what extent does this characterization describe you?

$\begin{array}{llllllc}1 & 2 & 3 & 4 & 5 & 6 & 7 \\ \text { not at all } & & & & & \text { a great deal }\end{array}$




\section{Perceived Stress Scale}

$0=$ Never $\quad 1=$ Almost Neve

$2=$ Sometimes

3 = Fairly Often

$4=$ Very Often

1.In the last month, how often have you been upset because of something that happened unexpectedly?

$\begin{array}{lllll}0 & 1 & 2 & 3 & 4\end{array}$

2.In the last month, how often have you felt that you were unable to control the important things in your life?

$\begin{array}{lllll}0 & 1 & 2 & 3 & 4\end{array}$

3.In the last month, how often have you felt nervous and "stressed"?
0
1
2
3
4

4. In the last month, how often have you felt confident about your ability to handle your personal problems?

$\begin{array}{lllll}0 & 1 & 2 & 3 & 4\end{array}$

5. In the last month, how often have you felt that things were going your way?
0
1
2
3
4

6. In the last month, how often have you found that you could not cope with all the things that you had to do?

$\begin{array}{lllll}0 & 1 & 2 & 3 & 4\end{array}$

7. In the last month, how often have you been able to control irritations in your life?

$\begin{array}{lllll}0 & 1 & 2 & 3 & 4\end{array}$

8. In the last month, how often have you felt that you were on top of things?

$\begin{array}{lllll}0 & 1 & 2 & 3 & 4\end{array}$

9. In the last month, how often have you been angered because of things that were outside of your control?
0
1
2
3
4

10.In the last month, how often have you felt difficulties were piling up so high that you could not overcome them?

0

1

2

3

4 


\section{Perceived Well-being Index}

\section{PART 1 [OPTIONAL ITEM]}

1. Thinking about your own life and personal circumstances, how satisfied are you with your life as a whole?

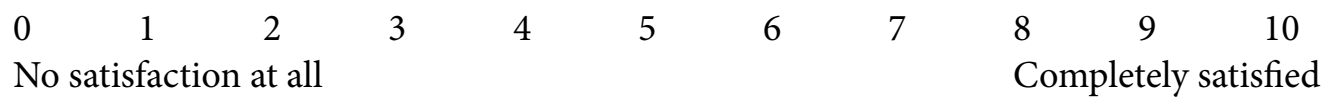

\section{PART 2}

1. How satisfied are you with your standard of living?

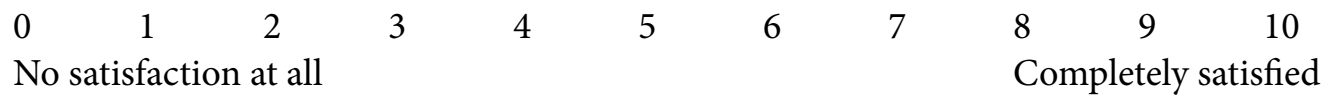

2. How satisfied are you with your health?

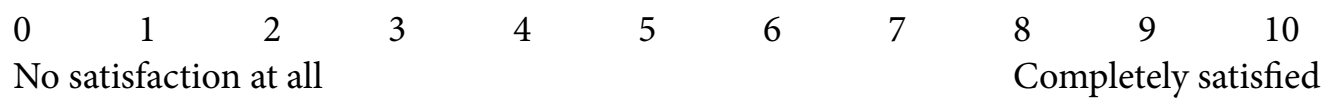

3. How satisfied are you with what you are achieving in life?

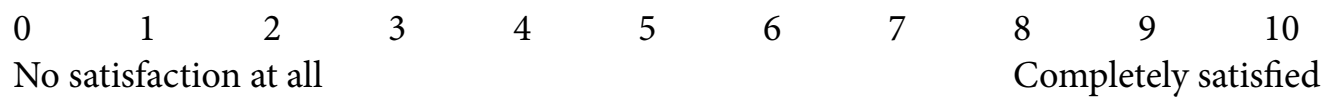

4. How satisfied are you with your personal relationships?

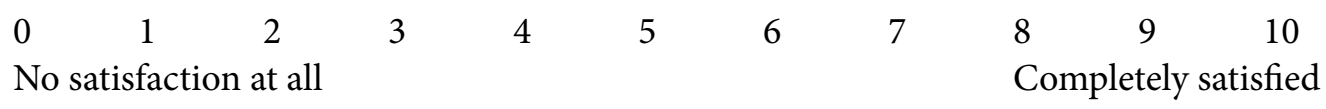

5. How satisfied are you with how safe you feel?

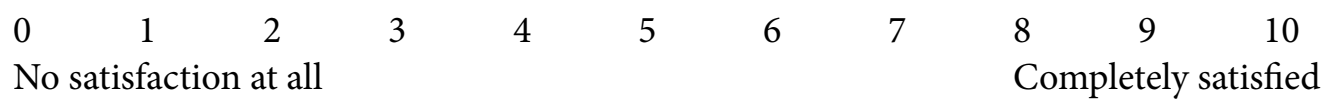

6. How satisfied are you with feeling part of your community?

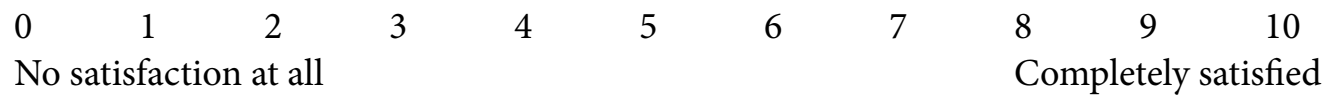

7. How satisfied are you with your future security?

$\begin{array}{lccccccccc}0 & 1 & 2 & 3 & 4 & 5 & 6 & 7 & 8 & 9 \\ \text { No satisfaction at all } & & & & & & & & \text { Completely satisfied }\end{array}$

\section{[OPTIONAL ITEM]}

8. How satisfied are you with your spirituality or religion?

$\begin{array}{lccccccccc}0 & 1 & 2 & 3 & 4 & 5 & 6 & 7 & 8 & 9 \\ \text { No satisfaction at all } & & & & & & & & \text { Completely satisfied }\end{array}$

